\section{Dr Jo Beenhakker \\ Treasurer WCPT-Africa}

The first Congress of the African Region of WCPT was held in Nairobi, Kenya from 8 - 11th April, 1994. Member countries of the Region present were Kenya, Nigeria, South Africa, Zambia and Zimbabwe, while observers and delegates from Botswana, Cameroon, Malawi, Namibia, Oman, Somalia, Tanzania and Uganda also participated. There were additional speakers and workshop leaders from Canada, England, Holland, Norway and Scotland.

The Region was privileged to have the President and General Secretary of WCPT, Professor AJ Fernando and Mrs Margaret $\mathrm{O}^{\prime}$ Hare Knight who attended both the General Meeting and Congress. WCPTAfrica was congratulated on being the first of the five regions to host a congress.

\section{GENERAL ASSEMBLY}

This was well attended by official delegates and observers from eleven African countries and old friendships were renewed and new links forged.

The meeting encouraged strong interregional links between member countries of WCPT-Africa and non members, in order to improve the awareness of physiotherapy in the various countries.

The executive committee has enjoyed good support and regular communication from Kenya, South Africa, Zambia and Zimbabwe, but the President, Mrs Dorcas Madzivire urged representatives to provide regular information for the regional newsletter. Communication between
WCPT-Europe and the African region has been fruitful and most helpful.

WCPT, which assisted African countries in the past with sponsorship of eight physiotherapists to the course in Malta, also funded the first congress flyer and assisted one delegate from each member country to the congress.

Reports were given by the five member organisations and useful information was shared. One of the problems facing most African countries was the lure of physiotherapists from these countries, where their services are so desperately needed, to America. One of the reasons was the poor conditions of service and low salaries paid in the public sector. Monthly salaries vary from 45 US dollars (plus housing) in Uganda, 126 US dollars in Zambia, 750 in South Africa and 850 in Nigeria. The meeting strongly recommended that various African Governments should be urged to review the prevailing conditions of service for physiotherapists. The need for mid-level workers was agreed to and the importance of Community-based rehabilitation was recognised. Governments are to be urged to consult with physiotherapists in setting up such programmes in the various countries. Finance of the Region remains a problem and methods of raising funds need to be found. We cannot rely solely on assistance from WCPT and WCPTEurope.

The President (Mrs Dorcas Madzivire) and Secretary (Mrs Marlene Brand) were re-elected for a further two year period and thanked for all the work done for the Region. Emma Sablerolles of Zambia be- comes the new Vice-President and Jo Beenhakker takes over the Treasurer's portfelio from Sheena Irwin-Carruthers.

Congress

Arranging the Congress was the biggest challenge yet for the region. The Kenya Society of Physiotherapy, under the chairmanship of Alfred Otieno did the groundwork in Nairobi, while the executive committee operated from Harare and formed the Scientific Congress Committee under the chairmanship of Jo Beenhakker.

The theme of the congress was Reach for Rehabilitation: Physiotherapy in a changing Africa. Because of the changing socio-economic and political changes taking place in Africa, it was hoped to provide a platform for all African physiotherapists to exchange ideas on the practice of physiotherapy on the continent.

Subjects covered in the congress and pre-congress workshops varied widely. These included Acupuncture, Industrial Back problems, orthopaedic manipulative therapy and Education. Papers were also given on Quality Assurance, Communitybased rehabilitation, specific health problems in Africa and community involvement in rehabilitation.

At special interest meetings, five interest groups were formed to promote interaction between member countries. These groups were Sports Injuries, Geriatrics, Neurology, Physiotherapy Education and Acupuncture.

The next General Meeting and Congress will be held in Zimbabwe in 1996 and hopefully many more South Africans will participate in this event.

\title{
THE UNIVERSITY OF THE WITWATERSRAND
}

will present a post-graduate course on

MYOFASCIAL PAIN AND DYSFINCTION, TRIGGER POINTS AND ADVERSE NEURAL TENSION

COURSE LEADER: Mrs D Sweatman - a private practitioner

from the Cape who is well known for the excellence of her courses.

\section{ASSISTANT: Claire Louw}

COURSE COORDINATORS: C Cunningham, L Hunter THIS COURSE WILL BE CERTIFICATED BY THE UNIVERSITY DATES: Friday 21 October - Sunday 23 October 1994 TIMES: Approximately 08h30-16h30 doily

VENUE: Proc Ll, Wits Physio Dept

COST: R400 to be sent with application lincludes R150 non-relurnable deposit). The fee will cover lunches, teas and comprehensive course notes.
NB: NUMBERS STRICTLY LIMITED TO 40

BOOKINGS: Return form below. Only written applications will be occepted

ENQllIRIES: Mrs Hawkins (011) 488-3450 Mondays to Fridays (mornings only)

CHEQUES payable 10 "University of the Witwatersrand"

\section{APPLICATION FORM: WITS POST-GRADUATE COURSE MYOFASCIAL PAIN AND DYSFUNCTION, TRIGGER POINTS, ADVERSE NEURAL TENSION 21 - 23 OCTOBER 1994, WITS PHYSIOTHERAPY DEPT}

NAME

ADDRESS

TEL NUMBERS: WORK

CODE

SAMDC REGISTRATION NO:

FEES: R400

FLEASE SEND YOUR APP.ICATION FORM, TOGETHER WITH YOUR OHEQUE, IO: PHYSIOTHERAPY DEPARIMENT (OCT COURSE), MEDICAL SOHOOL, 7 YORK ROAD, PARKTOWN JOHANNESBURG 2193. OHEQUES MAY BE MADE PAYABLF TO "UNNERSTTY OF THEWIWATERSRAND" 